\title{
CLASSIFICATION OF LANDS OF REMOTE SENSITIVE DATA BY NDVI METHOD IN SMART AGRICULTURE
}

\author{
Emin Farzaliyev \\ Karabuk University, Department of Computer Engineering, Karabuk, Turkey - ferzeliyevemin99@ gmail.com
}

KEYWORDS: Remote Sensing, NDVI, Near Infrared, Visible Red, MATLAB, Smart Agriculture

\begin{abstract}
:
A large share of the earth's surface is observed with remote sensing technology. Thanks to the data obtained from this process, information about the observed lands is obtained. In this study, NDVI (normalized difference), which is developed by applying mathematical operations on the reflection values of plants at different wavelengths from remote sensing technology and different application areas of this technology, electromagnetic rays, and spectral reflection values, and which is used as a method that provides a value expressing vegetation density. Vegetation index) method, NDVI value, and plant groups analyzed according to this value, sample MATLAB applications related to the NDVI method are mentioned. -Green-Blue) image of visible red and infrared regions, histogram graph showing the relationships between the intensities of values in NIR (near-infrared) and Red (visible Red) bands, NDVI image, and threshold function at the end. The NDVI image was obtained by using the direction (to detect areas that may have vegetation) is shown.
\end{abstract}

\section{INTRODUCTION}

Plants are significant for the continuation of the natural cycle in the world and our life. For this reason, the decrease and increase of plants should be controlled. It is possible to detect these changes using satellites. For this, electromagnetic waves are sent from satellites to regions with vegetation, and satellite receivers collect the region's response to these electromagnetic waves.

The collected data is processed in the system, and the results are obtained (Bozkurt et al., 2018). In this study, the NDVI method was used, one of the remote sensing methods. With this method, the health status of the vegetation in the region, the places where it is dense, and b. data can be obtained and used in the fields.

Thanks to the rapid development of remote sensing technology, the work done in areas that are difficult to reach and see with the human eye has gained speed. For example, we can say that data is collected from the field after forest fires (Sabuncu et al., 2019). The development of this technology, the observation and analysis of land cover change, and land use by satellites expand the application areas of remote sensing technology (Reis et al., 2020).

Today, remote Sensing is also essential for agricultural regions. The rapid growth of the world's population creates problems such as food and water shortages. When climate changes and droughts are added to these problems, the importance of remote sensing technologies increases (Üstüner et al., 2016). Remote sensing technologies are significant to professionally manage and monitor agricultural regions and direct agriculture and water consumption.

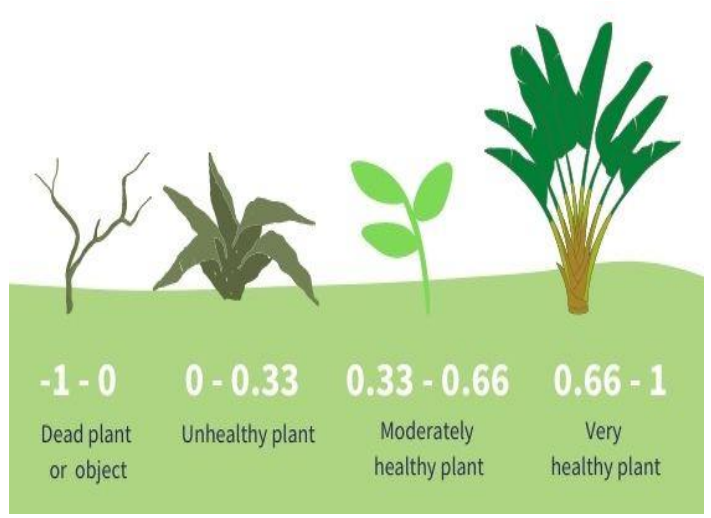

Figure 1. Plant groups with values in the range $[-1,+1]$.

Today, the remote sensing method is one of the most widely used methods in agricultural product pattern detection, and the most widely used method with satellite images is automatic image classification. In addition, maps of agricultural lands can be obtained with the obtained satellite images (Y1lmaz, 2018). Besides, agriculture is crucial for countries in terms of economy. With the information obtained through satellites, they can determine the number of products in agricultural lands, determine the countries' needs, and shape an agricultural policy accordingly. These technologies can provide information about the quality of the product and the amount of the product in the agricultural region faster and with higher accuracy than the terrestrial measurements. As a result of integrating remote sensing methods with Geographical Information Systems and their application to agricultural regions, complex analysis can be made about vegetation (Akkartal et al., 2005). 


\section{METHODOLOGY}

\subsection{Remote Sensing}

Remote Sensing is the technique of collecting information about any object on earth, without touching that object, by evaluating this information, processing, and applying it through receivers placed on satellites at a certain distance from the earth's surface. This technology is of great importance in temporal and spatial resolutions, especially in analyzing and tracking natural objects. Sensors or remote sensors measure electromagnetic rays that come into contact with the earth.

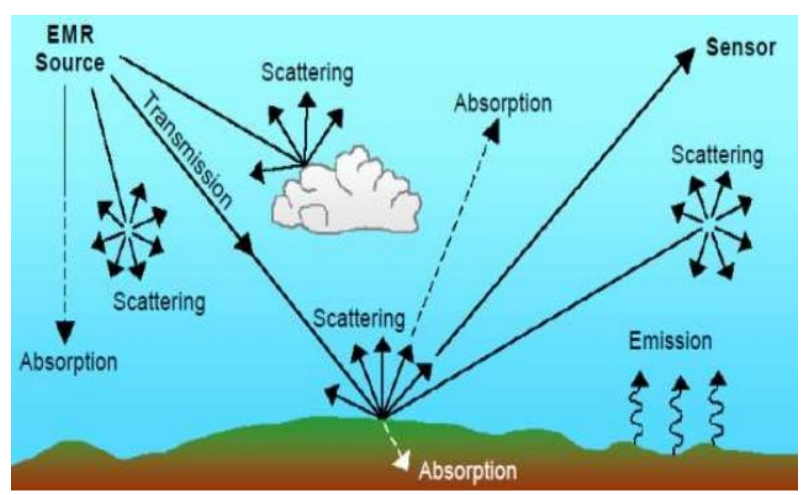

Figure 2. Electromagnetic rays and their interactions.
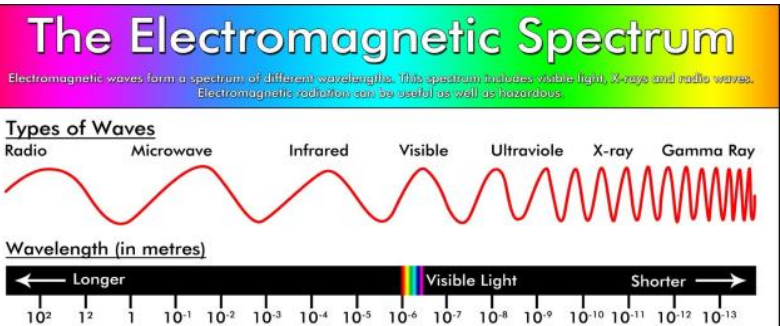
Frequency (waves per second) $\longleftarrow$ Lower $\begin{array}{llllllllllllllllll}0_{10}^{6} & 10^{7} & 10^{8} & 10^{9} & 10^{10} & 10^{11} & 10^{12} & 10^{13} & 10^{14} & 10^{15} & 10^{16} & 10^{17} & 10^{18} & 10^{19} & 10^{20} & 10^{21}\end{array}$ These Waves Are About the Size of:
Mountains Football Humans Honey Boo Pinpoint
Pitch

Figure 3. Electromagnetic Spectrum

Objects may differ in their reflectance properties, and the spectral reflectance curve represents this.

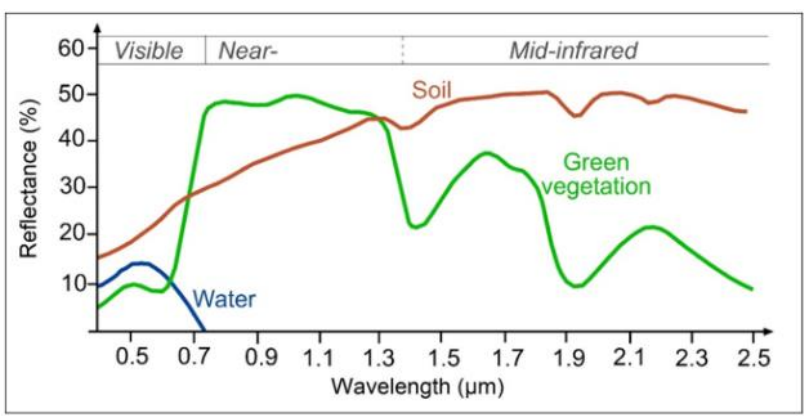

Figure 4. Spectral reflectance curve

In tree species, these species have different pigments, leaf surface, morphology, and water content causes them to have different reflection properties (Benliay et al., 2011).

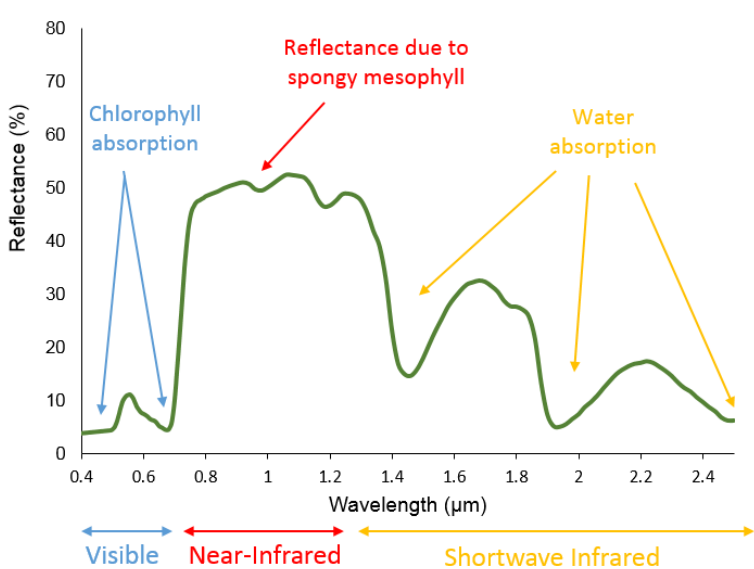

Figure 5. Spectral reflectance values (green vegetation)

\subsection{Normalized Difference Vegetation Index (NDVI)}

Plants use the sunlight and chlorophyll in their leaves to produce organic matter from inorganic matter. In the meantime, the share of the electromagnetic energy of the Sun corresponding to the red light and which is $0.63 \mu \mathrm{m}-0.69 \mu \mathrm{m}$ in length, is used. Plants do not absorb electromagnetic energies with waves of $0.7 \mu \mathrm{m}$ and are more significant and reflect them. Therefore, any satellite image measuring the reflection of nearinfrared electromagnetic energy will equal a high numerical value in the concentrated part of the vegetation(Gündoğdu, 2018).

The bands NDVI uses are red and near-infrared. The NDVI value is calculated with the following formula and obtains a value in the range of $[-1,+1]$.

$$
\mathrm{NDVI}=(\mathrm{NIR}-\mathrm{RED}) /(\mathrm{NIR}+\mathrm{RED})
$$

As a result of expanding this value to the range of [0,255], a new 8-bit image can be created, called normalization(Gündoğdu, 2018). Normalized Vegetation Index (NDVI) is used as a method that has been developed by applying mathematical operations on the reflectance values of plants at different wavelengths and provides a value that expresses the vegetation density. The NDVI method provides data expressing the feature of the plant by increasing the difference between the near-infrared and visible red bands in the electromagnetic spectrum or by collecting the information in these two bands in a single band. In calculating NDVI values on plant images, the numerical values of different bands, that is, the value of the pixel in the data band, are used. Because the values contained in the pixels in the image can be used as a distinguishing feature because they change depending on how much radiation the atmosphere, earth, and plant absorb and how much reflection it reflects on the sensor. The following equation obtains the NDVI values. Here, NIR stands for infrared reflection, and Red stands for reflection in the visible region. 


\section{HEALTHY STRESSED VEGETATION REFLECTANCE}
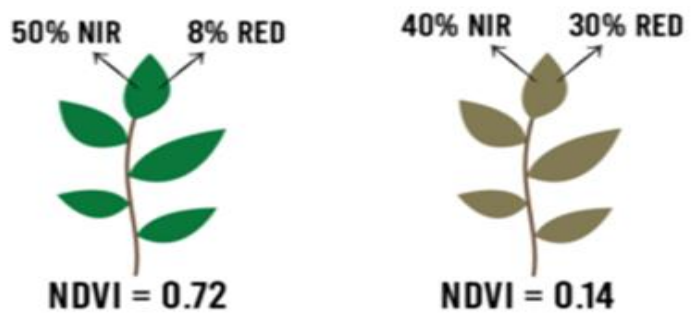

$$
\text { NDVI }=\frac{\text { NIR - RED }}{\text { NIR + RED }}
$$

Figure 6. Plant analysis according to NDVI value.

The primary purpose here is to provide information about the area of green, the natural color of the plant, by proportioning the normalized pixel values or the values reflected from the infrared band to the red band, to determine the places where the vegetation is dense and to find the areas without vegetation. The closer the value obtained from the NDVI calculation gets to the value of 1 , the closer the density of vegetation is, the closer it gets to the value of 0 , the more vegetation is lost. In the light of this information, we can understand the density of vegetation in an area and how healthy they are with the NDVI method.

\section{NDVI MATLAB APPLICATION}

The application is a study on the determination of vegetation in a particular area. In this application, the image is named Paris.lan embedded in the MATLAB code is taken as reference. First, the near-infrared (NIR), visible red band, and non-visible green band data of this image in the electromagnetic spectrum were read, and the image was reduced to 4,3 and 2 band images. These operations were carried out with the following MATLAB codes.

CIR = multibandread('paris.lan', [512, 512, 7], 'uint8=>uint8',... 128, 'bil', 'ieee-le', \{'Band','Direct',[ 4 $32]\})$;

figure imshow(CIR)

title('CIR First Image')

The screenshot of the resulting code is as follows:

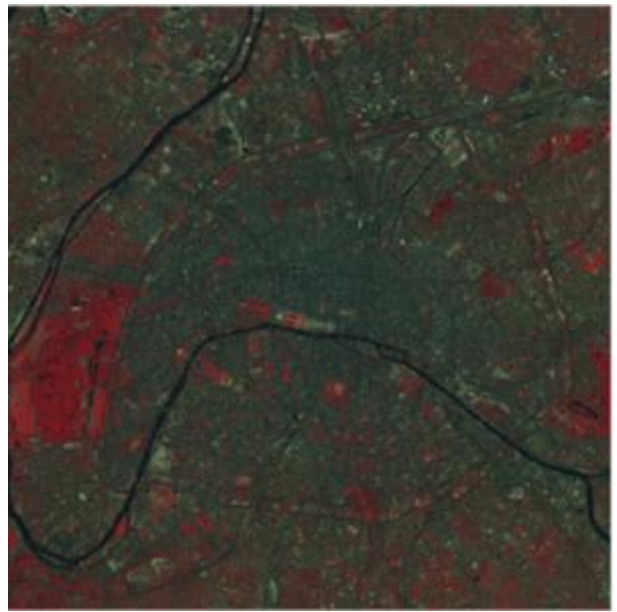

Figure 7. First view of the analyzed land.
In the next step, the decorstretch function is used. With this function, the color differences in the image obtained in the first step are clarified, and the transitions and lines in the image are sharpened.

decorrCIR = decorrstretch(CIR, 'Tol', 0.01);

figure

imshow(decorrCIR)

title('RGB Image');

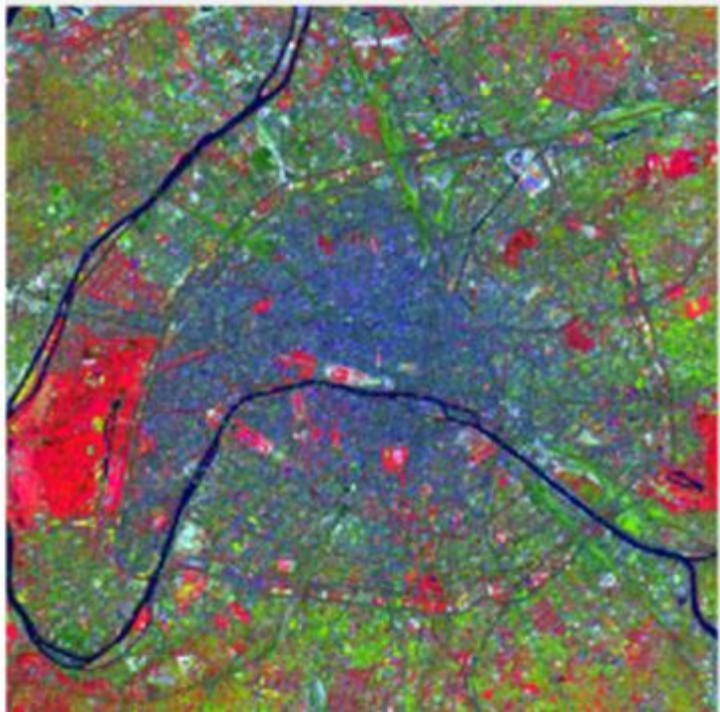

Figure 8. RGB image of the analyzed area.

In the application, the data in the near-infrared (NIR) and visible red (RED) bands used for NDVI calculation in the following process are assigned to the variables. Screenshots of the data on both tapes are as follows.

NIR = im2single(CIR(:,:,1));

red $=$ im2single $(\operatorname{CIR}(:,:, 2))$;

figure

imshow(red)

title('Visible Red Zones')

figure

imshow(NIR)

title('Infrared Zones');

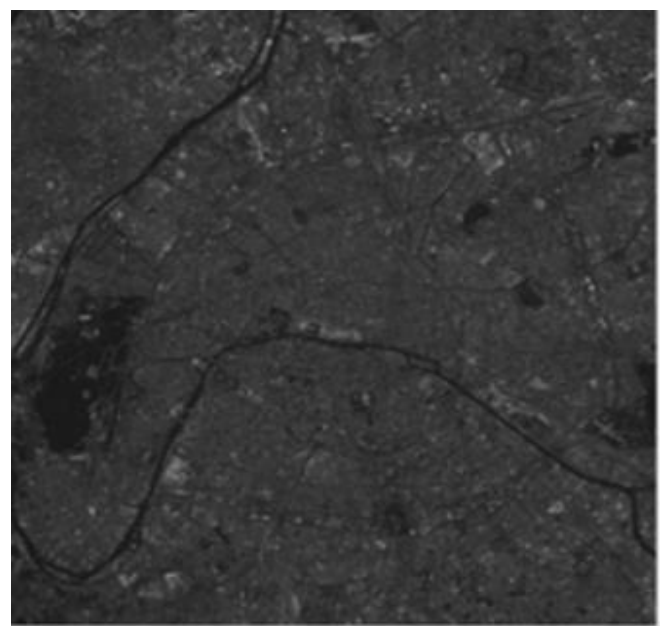

Figure 9. The image of the analyzed area is in the visible red band. 


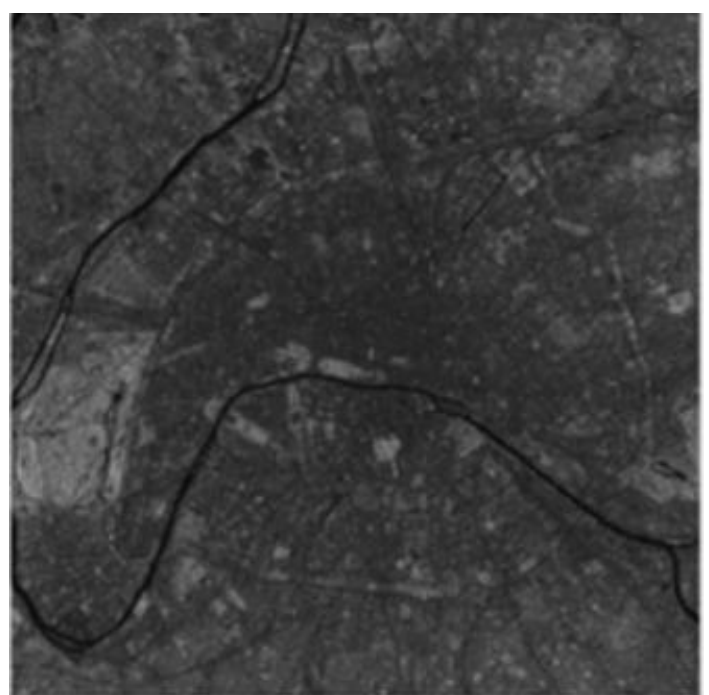

Figure 10. The image of the analyzed area in the near-infrared band.

Then, the relations between the intensities of the values in the NIR and Red bands on the obtained image can be shown by using the following function. The resulting graph is known as the histogram graph.

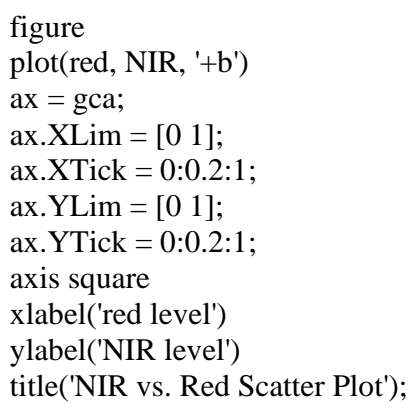

The resulting histogram graph image is as follows:

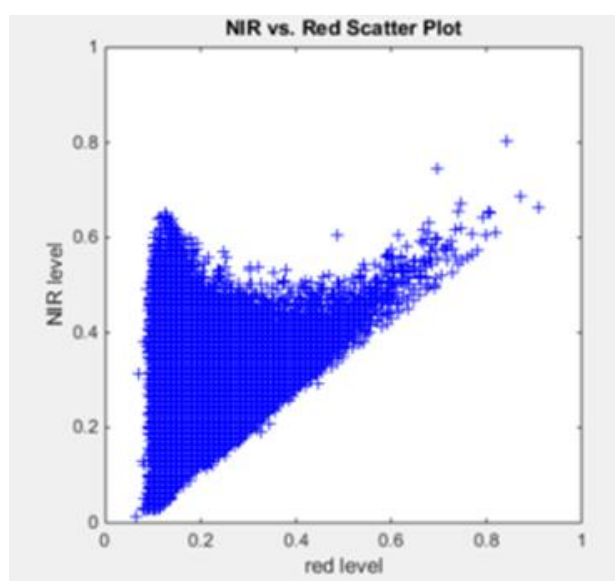

Figure 11. Histogram graph of the analyzed land.

The NDVI calculation is performed using the NIR and Red values obtained in the next step.

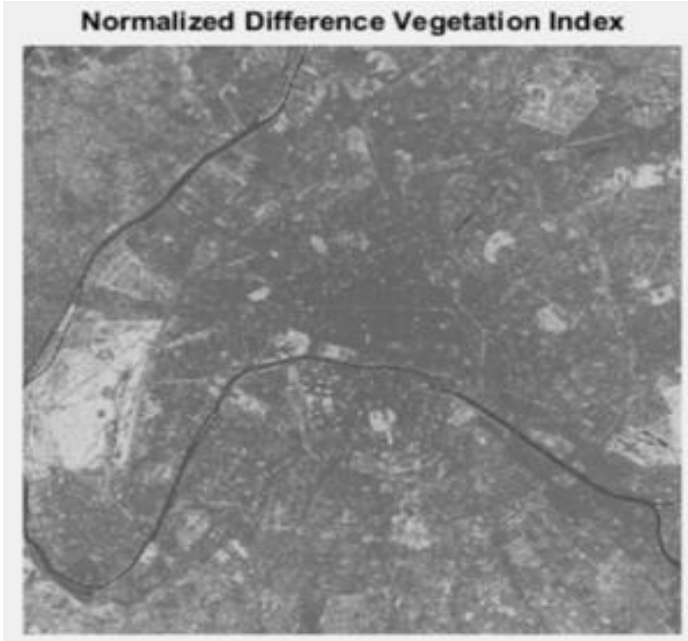

Figure 12. NDVI image of the analyzed land.

In the last stage, a threshold value should be determined using the threshold function to detect areas that may have vegetation. By comparing this threshold value with the calculated NDVI value, places that are likely to be vegetation can be determined. The NDVI value found is in the range of $[-1 ; 1]$ as stated at the beginning of the report. As the NDVI value approaches 1 , the areas that are likely to be vegetation will become more apparent, and as the NDVI value approaches zero, the areas that are likely to be vegetation will decrease. This situation should be taken into consideration, and the threshold value should be determined accordingly.

$$
\begin{aligned}
& \text { threshold }=0.4 ; / / \text { threshold value } \\
& q=(\text { ndvi }>\text { threshold }) ; \\
& \text { figure } \\
& \text { imshow(q) } \\
& \text { title('NDVI with Threshold Applied'); }
\end{aligned}
$$

The resulting image after using the Threshold function is as follows:

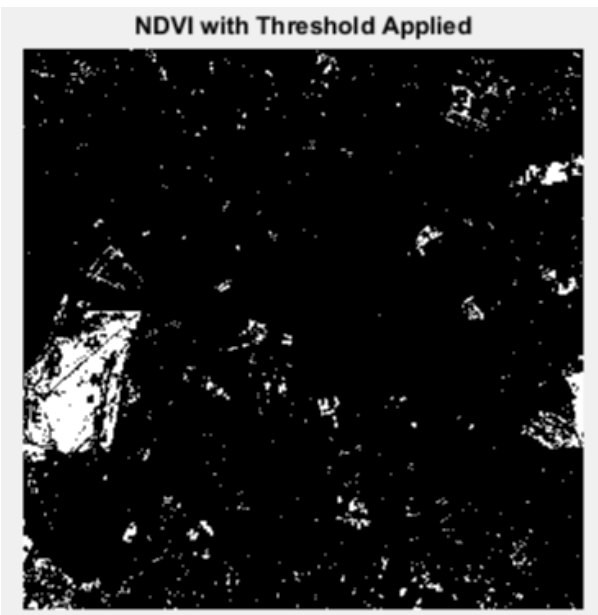

Figure 13. View of the analyzed terrain after using the Threshold function.

$\mathrm{NDVI}=(\mathrm{NIR}-\mathrm{RED}) /(\mathrm{NIR}+\mathrm{RED}) ;($ Koçan, 2021$)$ 


\section{CONCLUSION}

With the NDVI method and Matlab application, the region's image was obtained with MATLAB codes, taking the image named Paris.lan as reference. The color differences in the image obtained using the decorrstretch function were clarified, the transitions and lines in the image were sharpened. Then, the data in the near-infrared (NIR) and visible red (RED) bands were assigned to the variables, and new images were obtained. Histogram graph and NDVI image of the region were obtained. A threshold value was determined by using the threshold function to detect areas that may have cover, and by comparing this threshold value with the calculated NDVI value, places that are likely to be vegetation were determined.

\section{REFERENCES}

Akkartal, A., Türüdü, O., Erbek, F. S., Sözcükler, A., Tarım, Algılama, U., İndeksi, B. Ö., Zamanlı, Ç., \& Verisi, U., 2005. Çok zamanlı uydu görüntüleri ile bitki örtüsü değişim analizi, 18.

Ateşoğlu, A.,M.Tunay et al., 2010. Bartın Kıyı Alanlarında Bitki Örtüsü Değişim Analizi, Journal of Forestry Faculty, 10(1), 84-95.

Aydoğdu, M., Mermer, A., Ünal, E., Yıldız, H., Avağ, A., Urla, Ö., \& Ünal, S., 2013. Mera Vejetasyonunun Uydu Görüntüleri (Ndvi) Ile İzlenmesi. Journal of Chemical Information and Modeling, 53(9), 1689-1699, 1-6.

Benliay, A., Altuntas, A., \& Ortacesme, V., 2011. Peyzaj Değişimi Bağlamında Bitki Örtüsü Analizlerinde Kullanılan Uzaktan Algılama Teknikleri, October,1-15

Bozkurt, N. E., Zontul, M., \& Aslan, Z., 2018. Uydu verilerine dayali olarak bitki örtüsü analizi. 2(1), 75-82.

Çölkesen, İ., \& Yomralığlu, T. (2014). Arazi Örtüsü ve Kullanımının Haritalanmasında WorldView-2 Uydu Görüntüsü ve Yardımcı Verilerin Kullanımı. Harita Dergisi, Arazi Örtüsü ve Kullanımının Haritalanmasında WorldView-2 Uydu Görüntüsü ve Yardımcı Verilerin Kullanımı, 12-24.

Gündoğdu, K. S., 2018. Buğday Ekili Parsellerde NDVI Değerlerinin Konumsal ve Zamana Bağlı Değişiminin Belirlenmesi. Kahramanmaraş Sütçü İmam Üniversitesi Doğa Bilimleri Dergisi, 21(4), 492-499. https://doi.org/10.18016/ksudobil.364749

Kalkan, K., 2011. Kentsel gelişim için potansiyel açık alanların belirlenmesinde nesne tabanli siniflandirma yöntemi ile transfer edilebilir kural dizisi oluşturulması, 1-85.

Karadaş, S., \& İmamoğlu, A., 2019. Normalized Difference plant index analysis with remote sensing techniques ( NDVI) of Süvari Stream Basin. TMMOB 6.Coğrafi Bilgi Sistemleri Kongresi, 0534, 23-25.

Koçan, Y., 2021. Bitki örtüsü tespitinde sentinel 2-a ve yüksek çözünürlüklü insansız hava aracı görüntülerinin kıyaslanması. $0-4$.

Kayman, Ö., Sunar, F., 2015. Spektral indekslerin landsat tm uydu verileri kullanılarak arazi örtüsü/kullanımı sınıflandırmasına etkisi: İstanbul, Beylikdüzü ilçesi, arazi kullanımı değişimi. 52-59.
Özyavuz, M., 2011. Bitki Örtüsünün Ekolojik Şartlarının Coğrafi Bilgi Sistemleri ve Uzaktan Algılama Teknikleri ile Analizi, Ganos (Ișıklar) Dağı, Tekirdağ. JOTAF / Tekirdağ Ziraat Fakültesi Dergisi, 8(2), 37-47.

Polat, N., Kaya, Y., 2021. Çok Bantlı Uydu Görüntüleriyle Orman Yangınlarının Belirlenmesi ve Hasar Tespiti. Bartın Orman Fakültesi Dergisi, 23(1), 172-181. https://doi.org/10.24011/barofd.837507.

Reis, H. Ç., Yılancı, G., Bilimleri, D., \& Bölüm, H. M. (2020). Determination of cotton planted areas using support vector machines and NDVI : A case study of Harran plain. 2(52699), $31-41$.

Sabuncu, A., Özener, H., 2019. Uzaktan Algılama Teknikleri ile Yanmış Alanların Tespiti: İzmir Seferihisar Orman Yangını Örneği. Doğal Afetler ve Çevre Dergisi, 90(216), 1-9. https://doi.org/10.21324/dacd.511688.

Şentürk, Ü. G., 2020. Uztaktan Algılama Teknikleri Kullanarak Kayısı Bahçelerinin Tespiti ve Rekolte Tahmini: Malatya Battalgazi Örneği. Orphanet Journal of Rare Diseases, 21(1), 156.

Şimşek, F. F., Teke, M., \& Altuntaş, C., 2016. Uzaktan algılama tekniği ile tarim arazilerinde çiftçi ürün beyanlarının kontrolü : Harran Ovası Örneği, November,1-9.

Tunay, M., Ateşoğlu A. et al., 2008. Çok Zamanlı Uydu Görüntüleri ile Amasra Ve Yakın Çevresine Ait Bitki Örtüsü Değişim Analizi, 71-80.

Üstüner, M., Şanlı, F. B., \& Abdikan, S. (2016). Bitki Örtü İndekslerinin Tarımsal Ürün Deseni Tespitindeki Etkisinin Araştırılması. 5-7.

Yıldız, H., Mermer, A., Ünal, E., Akbaş, F., \& Bitkileri Merkez Araştırma Enstitüsü Müdürlüğü, T. (2012). Türkiye Bitki Örtüsünün NDVI Verileri ile Zamansal ve Mekansal Analizi. Tarla Bitkileri Merkez Araştırma Enstitüsü Dergisi, 21(2), 5056.

Y1lmaz, M., 2018. Object-Based Classification of Summer Crops From Sentinel-2 Satellite Images Using Random Forest Algorithm,1-78. 